\title{
Effects of lactic acid bacteria with bacteriocinogenic potential on the fermentation profile and chemical composition of alfalfa silage in tropical conditions
}

\author{
V. P. Silva, ${ }^{*}$ O. G. Pereira, ${ }^{* 1}$ E. S. Leandro, ${ }^{*}$ T. C. Da Silva, ${ }^{*}$ K. G. Ribeiro, ${ }^{*}$ H. C. Mantovani, $\dagger$ and S. A. Santos $\ddagger$ \\ *Departamento de Zootecnia, and \\ †Departamento de Microbiologia Agrícola, Universidade Federal de Vicosa, Vicosa, Minas Gerais, Brazil 36570000 \\ ¥Departamento de Zootecnia, Universidade Federal da Bahia, Bahia, Brazil 40170110
}

\begin{abstract}
The fermentation profile, chemical composition, and microbial populations of alfalfa silages treated with microbial inoculants (MI) at different fermentation periods $(\mathrm{T})$ were evaluated in tropical conditions. A $4 \times 6$ factorial arrangement was used in a randomized design with 3 replicates. Fresh alfalfa was treated with (1) no treatment (CTRL), (2) commercial inoculant (CIN), (3) Pediococcus acidilactici (strain 10.6, S1), and (4) Pediococcus pentosaceus (strain 6.16, S2). An inoculant application rate of $10^{6} \mathrm{cfu} / \mathrm{g}$ of fresh forage was used. The fermentation periods were $1,3,7,14,28$, and 56 d. Alfalfa was harvested $82 \mathrm{~d}$ after sowing at the early flowering stage, chopped into $1.5-\mathrm{cm}$ particle size, and ensiled in $25 \times 35 \mathrm{~cm}$ vacuum-sealed plastic bags. The numbers of lactic acid bacteria, enterobacteria, mold, and yeast in alfalfa before ensiling were 5.42, 5.58, 4.82, and $4.8 \mathrm{log} \mathrm{cfu} / \mathrm{g}$, respectively. Silage chemical composition was evaluated only at $56 \mathrm{~d}$. All parameters were affected by the interaction MI $\times \mathrm{T}$, except the concentrations of lactic and propionic acids. Alfalfa silage treated with $\mathrm{S} 1$ or $\mathrm{S} 2$ had lower $\mathrm{pH}$ values than CTRL from the first day until $28 \mathrm{~d}$. However, the inoculants resulted in similar $\mathrm{pH}$ after $56 \mathrm{~d}$, and these values were lower than the CTRL. The highest concentration of lactic acid was observed in the silage treated with S1 and $\mathrm{S} 2$ at 7 and $14 \mathrm{~d}$ of ensiling. The concentration of acetic acid was lower in the silages treated with S1 and S2 than the CTRL and CIN at 3 and $28 \mathrm{~d}$ of fermentation. There was no effect of MI or MI $\times \mathrm{T}$ interaction on the microbial populations. However, the number of enterobacteria decreased over the fermentation period until $14 \mathrm{~d}$ and increased slightly after this
\end{abstract}

Received May 7, 2015.

Accepted November 24, 2015

${ }^{1}$ Corresponding author: odilon@ufv.br time point. The chemical composition of alfalfa silage was not affected by MI at $56 \mathrm{~d}$ of ensiling. The strain $P$. pentosaceus 6.16 was the most efficient in dominating the fermentation process by decreasing the $\mathrm{pH}$ more quickly and increasing the concentration of lactic acid, suggesting its potential use as a silage inoculant.

Key words: inoculant, lactic acid bacteria, organic acid, alfalfa silage

\section{INTRODUCTION}

Alfalfa (Medicago sativa) is the main legume used for silage production in the world because of its nutritional quality (Kung et al., 2003; Coblentz et al., 2014). However, the fermentation process and chemical composition of alfalfa silage have not been studied in tropical regions (Rangrab et al., 2000; Magalhães and Rodrigues, 2003).

Alfalfa has shown the same limitations for silage production under tropical conditions as in other regions, including low concentration of DM and water-soluble carbohydrates (Dewhurst et al., 2003) as well high buffering capacity (McDonald and Henderson, 1962). Wilting is usually performed after harvesting to increase DM content and decrease the growth of clostridial bacteria. Clostridia growth increases butyric acid and proteolysis in legume silages (Muck and Kung, 2007).

Homofermentative lactic acid bacteria (LAB) are widely used as inoculants, and their effects on increasing the concentration of lactic acid while lowering the $\mathrm{pH}$ and the concentration of ammonia nitrogen have been reported in the literature (Bolsen et al., 1992; Filya et al., 2007; Contreras-Govea et al., 2011). However, studies conducted in Brazil have not shown that LAB inoculants improve alfalfa fermentation (Rangrab et al., 2000; Rodrigues et al., 2004). This suggests that environmental conditions encountered in the tropics can affect the physiology and metabolism of the inoculated strains and may influence their effects on the fermentation process. In addition, the success of an inoculant 
in the silage depends on its ability to grow fast, the presence of substrate, and the relationship between the application rate and the epiphytic population in the forage (Muck, 1988). Recently, strains of LAB that produce bacteriocins have been proposed to control the growth of spoilage microorganisms in silages because of their antimicrobial activity (Mantovani and Russell, 2003; Amado et al., 2012). The results have shown better efficiency in improving the fermentation profile of grass silages (Mantovani and Russell, 2003; Amado et al., 2012; Ferreira et al., 2013). Based on those results, Silva et al. (2012) performed a screening of LAB with bacteriocinogenic activity isolated from silages of a tropical legume and found a few strains with antimicrobial activity from a bacteriocin-like substance. However, the effect of these strains on the fermentation of legume silages in tropical conditions has not yet been evaluated.

We hypothesize that using LAB with bacteriocinogenic potential isolated from a tropical-legume silage enhances the fermentation profile of alfalfa silage under tropical conditions. Therefore, this study aimed to quantify the microbial populations and to evaluate changes in the fermentation profile and chemical composition of alfalfa silages treated with microbial inoculants.

\section{MATERIALS AND METHODS}

\section{Location and Silage Preparation}

The experiment was conducted at the Animal Science Department of the Federal University of Viçosa (Universidade Federal de Viçosa; UFV) located in Viçosa, Minas Gerais, Brazil, between May and July 2013. Viçosa is located at $20^{\circ} 45^{\prime} \mathrm{S}, 42^{\circ} 51^{\prime} \mathrm{W}$, and 657 $\mathrm{m}$ above sea level with a mean annual rainfall of 1,341 $\mathrm{mm}$.

Alfalfa cv. 'Crioula' was grown in a $1,000-\mathrm{m}^{2}$ area at the Forage Crops Sector of the Animal Science Department of UFV. Alfalfa was harvested $82 \mathrm{~d}$ after sowing, at the early flowering stage, using a backpack mower. After $6 \mathrm{~h}$ wilting, the alfalfa $(313 \mathrm{~g} / \mathrm{kg}$ of average DM) was chopped into $1.5-\mathrm{cm}$ particle size in a stationary forage chopper (model PN Plus 2000, Nogueira S.A., São João da Boa Vista, Brazil). Three replicated piles (each pile treated individually) containing approximately $12 \mathrm{~kg}$ of fresh alfalfa were prepared for each treatment (for a total of 12 piles). A total of $500 \mathrm{~g}$ of fresh alfalfa was packed into nylon-polyethylene bags $(25 \times 35 \mathrm{~cm}$; Doug Care Equipment Inc., Springville, $\mathrm{CA}$ ), and the air was evacuated from the bags using a vacuum sealer (Eco vacuum 1040, Orved, Italy). The bags were stored in the laboratory at room temperature (range, $23-27^{\circ} \mathrm{C}$ ).

\section{Experimental Design and Inoculant Application}

A $4 \times 6$ factorial scheme $(4$ inoculants $\times 6$ fermentation periods) was used in the randomized design with 3 replicates. The fermentation periods were $1,3,7,14$, 28 , and $56 \mathrm{~d}$. The periods were defined to describe with more details the alterations in the early fermentation (e.g., pH, organic acids), because the major changes occur during that time, according to previous study (Santos et al., 2014). The inoculants evaluated were (1) control (CTRL), (2) commercial inoculant (CIN), (3) Pediococcus acidilactici (strain 10.6, S1), and (4) Pediococcus pentosaceus (strain 6.16, S2). The commercial inoculant used was Sil-All $4 \times 4$ W.S. (Alltech, Sao Paulo, Brazil), which contains sucrose, Lactobacillus plantarum, P. acidilactici, Enterococcus faecium, Lactobacillus salivarus ssp. salivarus, silicon dioxide, amylase, cellulase, hemicellulase, and xylanase. An inoculant application rate of $10^{6} \mathrm{cfu} / \mathrm{g}$ of fresh forage was used, and the inoculants were diluted in distilled water. The same quantity of water used to dilute them was applied to the CTRL. The S1 and S2 strains were isolated from Stylosanthes silage (Stylosanthes macrocephala $\times$ Stylosanthes capitata cv. Campo Grande), and were provided by the Anaerobic Microbiology Laboratory of the Department of Agricultural Microbiology of UFV (Silva et al., 2012). The screening process aimed to find strains with bacteriocinogenic activity, and among 256 isolates, the S1 and S2 strains showed antimicrobial activity against 6 different microorganisms (Listeria monocytogenes ATCC 7644, Alicyclobacillus acidoterrestris DSMZ 2498, Lactococcus lactis ATCC 19435, Staphylococcus aureus ATCC 25923, Micrococcus luteus ATCC 10240, and Streptococcus bovis JB1). The S1 and S2 strains also exhibited high growth rate, and their acid-free extracts were sensitive to proteinase, indicating its proteinaceous nature (Silva et al., 2012).

\section{Chemical, Microbiological, Fermentation Profile, and Statistical Analyses}

Chemical Analysis. Samples of fresh alfalfa and its silages were dried in a forced-air oven at $55^{\circ} \mathrm{C}$ for $72 \mathrm{~h}$, and then ground in a Willey mill with a $1-\mathrm{mm}$ sieve. The concentrations of DM (method 934.01), CP (method 984.13), ash (method 942.05), ether extract (method 920.39), and ADF (method 973.18) were analyzed as described by the Association of Official Analytical Chemists (AOAC, 1990). For the NDF analysis, samples were treated with heat-stable $\alpha$-amylase without use of sodium sulfite and were corrected for residual ash (Mertens, 2002). Correction of the NDF and ADF for nitrogen compounds and estimation of NDIN and ADIN were performed according to Licitra et al. (1996). 
The concentration of lignin was determined through cellulose solubilization with sulfuric acid (Van Soest and Robertson, 1985). The concentration of NFC was calculated according to Detmann and Valadares Filho (2010), and the water-soluble carbohydrates were analyzed only in the forage before ensiling (Deriaz, 1961).

Microbiological Analysis. The microbial populations were quantified in the fresh forage and silages in all fermentation periods. The water extracts from the silage and fresh forage samples were prepared by homogenizing $25 \mathrm{~g}$ of sample in $225 \mathrm{~mL}$ of sterile Ringer's solution (Oxoid, Basingstoke, UK) in an industrial blender for $1 \mathrm{~min}$. Subsequently, the $\mathrm{pH}$ of the extracts was measured using a potentiometer. The water extract was divided into 2 portions. One portion was subjected to serial dilutions ranging from $10^{-1}$ to $10^{-10}$. Sterile plates were prepared with De Man, Rogosa and Sharpe agar (Difco, Sao Paulo, Brazil) for LAB, violet red bile agar (Difco) for enterobacteria, and potato dextrose agar (Difco) for yeasts and molds (Y\&M) (acidified with $1.5 \%$ of tartaric acid solution $10 \% \mathrm{wt} / \mathrm{vol}$ ). Plates of LAB and enterobacteria were incubated aerobically at $37^{\circ} \mathrm{C}$ for $48 \mathrm{~h}$, and the $\mathrm{Y} \& \mathrm{M}$ plates were incubated at $25^{\circ} \mathrm{C}$ for $4 \mathrm{~d}$.

Fermentation Profile. A portion of the water extract was filtered using Whatman 54 filter paper (Whatman Inc., Clifton, NJ), and acidified with metaphosphoric acid solution (20\% wt/vol) and centrifuged at $21,130 \times g$ for $15 \mathrm{~min}$ at ambient temperature to determine the concentration of lactic, acetic, butyric, and propionic acids in a Shimadzu HPLC (Shimadzu Scientific Instruments, Columbia, MD) coupled to a UV detector, model SPD-10A VP using $210 \mathrm{~nm}$ as the wavelength. To determine the $\mathrm{NH}_{3}-\mathrm{N}$ content, samples $(25 \mathrm{~g})$ from the mini-silos at all opening times were stored in plastic containers with $200 \mathrm{~mL}$ of $0.2 \mathrm{~N}-\mathrm{H}_{2} \mathrm{SO}_{4}$ $(5.61 \mathrm{~mL} / \mathrm{L})$ for $48 \mathrm{~h}$ under refrigeration. The extract was then filtered through 2 layers of cheesecloth and frozen at $-20^{\circ} \mathrm{C}$ for subsequent analysis according Bolsen et al. (1992).

Statistical Analysis. For the fermentation profile and microbial counts, a scheme of time-repeated measurements was used to repeat the fermentation periods $(1,3,7,14,28$, and $56 \mathrm{~d}$ after ensiling) within each experimental unit (silo). The model included the fixed effects of MI, T, and the interaction MI $\times \mathrm{T}$. Data from microbial counts were transformed into the logarithmic base ( $\left.\log _{10} \mathrm{cfu}\right)$ and subjected to the ShapiroWilk normality test to check whether the data follow the normal distribution. In the case of adequacy to the normal distribution $(P>0.05)$, the data followed the procedures outlined above for the other variables from the fermentation profile. In the case of non-normal distribution, the Poisson distribution was assigned to the data using the PROC GENMOD of SAS software (version 9.1, SAS Institute Inc., Cary, NC). The chemical composition of silages evaluated only at $56 \mathrm{~d}$ was also compared among inoculants using the differences between the estimated least squares means. The differences between estimated least squares means were assessed using the Predicted Difference (DIFF) option of the PROC MIXED of SAS software (version 9.1), considering 0.05 to be the maximum probability level for comparisons among inoculants.

\section{RESULTS AND DISCUSSION}

The chemical composition and population of microorganisms before ensiling are shown in Table 1. The $\mathrm{DM}$ content and the number of LAB in fresh alfalfa were adequate, considering the recommendation of 5 $\log \mathrm{cfu} / \mathrm{g}$ as a minimum required to minimize the losses during the fermentation process (Muck, 1996).

The $P$-value and SEM of fermentation characteristics of alfalfa silages are shown in Table 2 . There was an effect of $\mathrm{MI} \times \mathrm{T}$ interaction $(P<0.05)$ on all parameters evaluated, except for the concentrations of lactic acid and propionic acid $(P>0.05)$.

The DM content was different among treatments $(P$ $<0.05$ ) only at $14 \mathrm{~d}$, with higher values observed in silages treated with S1 and S2 (Figure 1a). When the fermentation is too intense, the high production of $\mathrm{CO}_{2}$ increases the DM loss and the DM content may decrease, as observed in sugarcane silages (Pedroso et al., 2005). Therefore, the slight differences in DM content observed at $14 \mathrm{~d}$ could be explained by the high levels of acetic acid observed in the CTRL and CIN silages. Alfalfa silage treated with microbial inoculants showed lower concentration of CP compared with the CTRL

Table 1. Chemical composition (g/kg of DM, unless otherwise stated) and microbial population (fresh weight basis) in alfalfa before ensiling

\begin{tabular}{lc}
\hline Item & Fresh alfalfa \\
\hline $\mathrm{DM}\left(\mathrm{g} / \mathrm{kg}\right.$ of $\left.\mathrm{NM}^{1}\right)$ & 313.0 \\
$\mathrm{CP}$ & 197.3 \\
$\mathrm{NDF}$ & 374.3 \\
$\mathrm{NFC}$ & 257.1 \\
Lignin & 59.7 \\
Ash & 156.8 \\
$\mathrm{ADIN}\left(\mathrm{g} / \mathrm{kg}\right.$ of $\left.\mathrm{TN}^{2}\right)$ & 57.8 \\
$\mathrm{WSC}^{3}$ & 51.9 \\
$\mathrm{LAB}^{4}(\log \mathrm{cfu} / \mathrm{g})$ & 5.42 \\
Enterobacteria $(\log \mathrm{cfu} / \mathrm{g})$ & 5.68 \\
Molds $(\log \mathrm{cfu} / \mathrm{g})$ & 4.82 \\
Yeasts $(\log \mathrm{cfu} / \mathrm{g})$ & 4.80 \\
$\mathrm{pH}$ & 6.07 \\
\hline
\end{tabular}

\footnotetext{
${ }^{1}$ Natural matter.

${ }^{2}$ Total nitrogen.

${ }^{3}$ Water-soluble carbohydrates.

${ }^{4}$ Lactic acid bacteria.
} 
Table 2. Statistical analysis for the fermentation profile variables of alfalfa silages treated with inoculants at different fermentation periods

\begin{tabular}{lcccc}
\hline & \multicolumn{3}{c}{$P$-value } \\
\cline { 2 - 4 } Item & Inoculant & Period & Inoculant $\times$ period & \multirow{2}{*}{ SEM } \\
\hline DM & $<0.01$ & $<0.01$ & $<0.01$ & 0.27 \\
$\mathrm{CP}$ & 0.37 & $<0.01$ & $<0.01$ & 0.31 \\
$\mathrm{pH}$ & $<0.01$ & $<0.01$ & $<0.01$ & 0.03 \\
Ammonia N & $<0.01$ & $<0.01$ & $<0.01$ & 0.19 \\
Lactic acid & $<0.01$ & $<0.01$ & $<.06$ & 0.27 \\
Acetic acid & $<0.01$ & $<0.01$ & $<0.01$ & 0.11 \\
Butyric acid & 0.08 & $<0.01$ & 0.01 & 0.52 \\
Propionic acid & 0.24 & $<0.01$ & 0.06 & 0.28 \\
\hline
\end{tabular}

at $3 \mathrm{~d}$ of ensiling. However, the CIN resulted in higher concentration of CP than the CTRL silage (Figure $1 \mathrm{~b}$ ) at $56 \mathrm{~d}$. Reductions in the concentration of $\mathrm{CP}$ could be due to its degradation, which increases the production of ammonia nitrogen. Based on that, the high concentration of $\mathrm{NH}_{3}-\mathrm{N}$ observed for the nontreated silages could explain the lower CP content.

Alfalfa silage treated with $\mathrm{S} 1$ or $\mathrm{S} 2$ had lower $\mathrm{pH}$ values than CTRL from the first day until $28 \mathrm{~d}(P<$ 0.05 ; Figure 2a). However, the inoculants resulted in similar $\mathrm{pH}(P>0.05)$ after $56 \mathrm{~d}$, and these values were lower than the CTRL (Figure 2a). Effect of MI on the $\mathrm{NH}_{3}-\mathrm{N}$ concentration was observed at $7,14,28$, and 56 d $(P<0.05)$. The silage treated with $\mathrm{S} 2$ showed the lowest concentration of $\mathrm{NH}_{3}-\mathrm{N}$ only at $28 \mathrm{~d}$, but by 56 d postensiling, $\mathrm{NH}_{3}-\mathrm{N}$ levels were similar to those in the CIN-treated silages (Figure 2b). Some studies with inoculants in alfalfa silage have evaluated the $\mathrm{pH}$ only after $50 \mathrm{~d}$ of ensiling (Rodrigues et al., 2004; Filya et al., 2007; Contreras-Govea et al., 2011), which does not provide details about how fast the $\mathrm{pH}$ drops during the beginning of the fermentation process (Whiter and Kung, 2001). If we observe the $\mathrm{pH}$ only at $56 \mathrm{~d}$, all inoculants had similar values. However, the strains with potential bacteriocinogenic activity lowered the $\mathrm{pH}$ from the first day of fermentation, which indicates their ability to grow faster and produce lactic acid. The fast drop in the $\mathrm{pH}$ is desirable because spoilage microorganisms under anaerobic condition are inhibited by a sufficiently low pH (Muck, 2010), thus increasing the DM recovery. In addition, the final $\mathrm{pH}$ values $(56 \mathrm{~d}$ ) can be considered adequate for legume silages, which usually stabilize when the $\mathrm{pH}$ drops to between 4.5 and 4.9 (Heinritz et al., 2012).

The high concentrations of $\mathrm{NH}_{3}-\mathrm{N}$, low concentration of lactic acid, and high $\mathrm{pH}$ observed in the CTRL silage at the early fermentation periods suggest that secondary fermentations occurred due to the activity of enterobacteria and bacteria of the genus Clostridium. The fast drop in the $\mathrm{pH}$ inhibits the growth of undesirable microorganisms, which probably occurred in the silages treated with S2, resulting in lower ammonia values.

The concentrations of lactic acid were different among treatments at 7, 14, and $56 \mathrm{~d}(P<0.05$; Figure $3 a)$. Silages treated with S1 and S2 showed higher concentrations of lactic acid than the other treatments at 7 and $14 \mathrm{~d}$. At $56 \mathrm{~d}$ postensiling the CIN-treated silage showed the lowest concentration of lactic acid, whereas the other treatments were similar. The concentration of acetic acid was lower in the silages treated with $\mathrm{S} 1$ and S2 than the CTRL and CIN at 3 and $28 \mathrm{~d}$ of fermentation $(P<0.05$; Figure $3 \mathrm{~b})$. After $56 \mathrm{~d}$, the S2-treated silages had lower concentration of acetic acid compared with CTRL and S1, but these concentrations were similar to that of CIN. The concentration of butyric acid was different among treatments at $1,3,28$, and $56 \mathrm{~d}$ of ensiling $(P<0.05)$. At $56 \mathrm{~d}$ of fermentation, the CTRL and S2 had lower concentrations of butyric acid than the alfalfa treated with CIN. Concentrations of propionic acid were similar among treatments at the different fermentation periods, except for the $7 \mathrm{~d}$, where the CTRL showed the highest concentration.

The decrease in the lactic acid concentration in the alfalfa treated with S1 after $14 \mathrm{~d}$ may have resulted from the presence of clostridia because these organisms are potential consumers of lactate. In addition, some heterofermentative bacteria are able to reduce lactic acid under aerobic and anaerobic conditions (OudeElferink et al., 2001). The decrease in the levels of this acid from d 14 to the final day of fermentation could be explained by the conversion of lactic acid into butyric acid. However, this hypothesis does not explain the trend observed because all silages exhibited low butyric acid concentrations. The higher concentration of acetic acid in the CTRL and CIN-treated silages than S1 and S2 in the early fermentation periods may be associated with a slower drop in the $\mathrm{pH}$, which suggests the low efficacy of the epiphytic LAB and the CIN in dominating the fermentation process. However, the acetic acid concentrations at $56 \mathrm{~d}$ in all silages were 
lower than $20 \mathrm{~g} / \mathrm{kg}$, which is the value set by Mahanna (1994) as adequate in well-fermented silages. The concentration of butyric acid also indicated well-fermented silages according to the same author. Silages treated with S2 showed low concentrations of acetic acid over the fermentation periods, which could result in higher DM recovery compared with the other treatments, and indicates the predominance of homolactic fermentation. Propionic acid was different among treatments only on $7 \mathrm{~d}$, and the highest values were observed in the CTRL silage $(P>0.05)$. This observation may have resulted from secondary fermentations, especially because the concentrations of lactic acid was lower in this silage during this period.

(a)

$\because \mathrm{CTRL}=\mathrm{CIN} \backsim \mathrm{S} 1 \backsim \mathrm{S} 2$

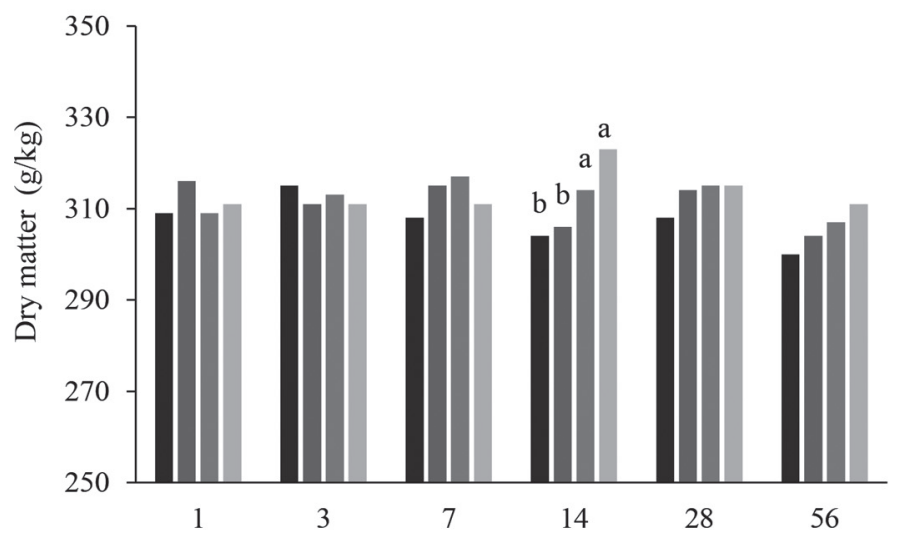

(b)

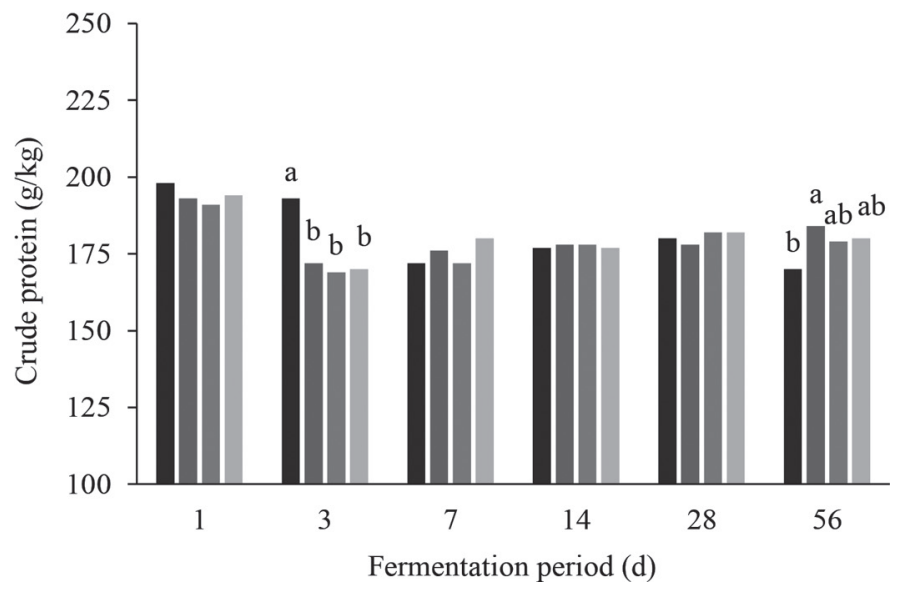

Figure 1. The DM (a) and CP (b) contents in alfalfa silages as a function of microbial inoculant within each fermentation period. Means followed by different letters $(\mathrm{a}, \mathrm{b})$ are different according to the predicted difference $(P<0.05)$. CTRL $=$ control (without inoculant); CIN $=$ commercial inoculant, Sil-All $4 \times 4$ W.S. (Alltech, Sao Paulo, Brazil); S1 = Pediococcus acidilactici, strain 10.6; S2 = Pediococcus pentosaceus, strain 6.16 .

The patterns of LAB, enterobacteria, and Y\&M counts over the fermentation period are shown in Figure 4. No effects $(P>0.05)$ were found of MI and MI $\times \mathrm{T}$ interaction on the microbial populations. However, we observed an effect of fermentation period on the population of enterobacteria $(P<0.05$; Table 3$)$. The number of enterobacteria decreased over the fermentation period until $14 \mathrm{~d}$ and increased slightly from this point (Figure 4). The fast initial acidification is the key to controlling the growth of enterobacteria and clostridia, which can grow until an inhibitory concentration of nondissociated acids, sufficiently low $\mathrm{pH}$, or both, are reached (Pahlow et al., 2003). The population of enterobacteria and their rate of decline could be used as accurate indicators of silage quality. Enterobacteria ini-

(a)

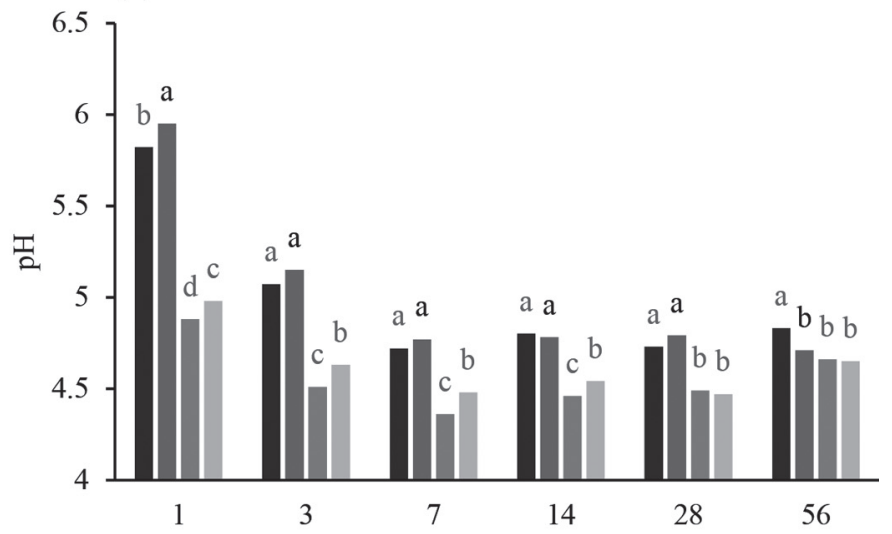

(b)

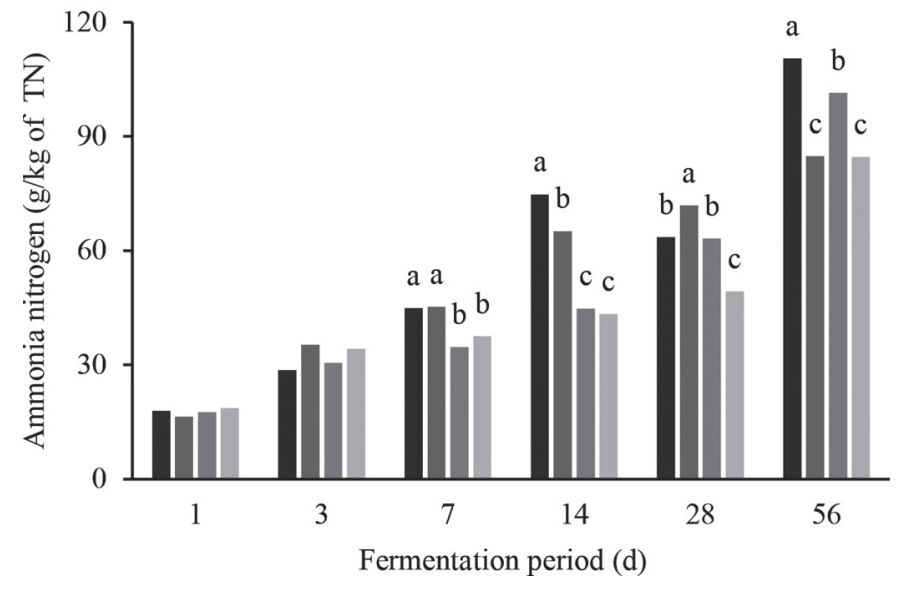

Figure 2. The $\mathrm{pH}(\mathrm{a})$ and $\mathrm{NH}_{3}-\mathrm{N}$ (b) values of alfalfa silages as a function of microbial inoculant within each fermentation period. Means followed by different letters $(\mathrm{a}-\mathrm{d})$ are different according to the predicted difference $(P<0.05)$. CTRL $=$ control (without inoculant); $\mathrm{CIN}=$ commercial inoculant, Sil-All $4 \times 4$ W.S. (Alltech, Sao Paulo, Brazil); S1 = Pediococcus acidilactici, strain 10.6; S2 = Pediococcus pentosaceus, strain 6.16 . 
$\because \mathrm{CTRL}=\mathrm{CIN} \backsim \mathrm{S} 1 \quad \mathrm{~S} 2$

(a)

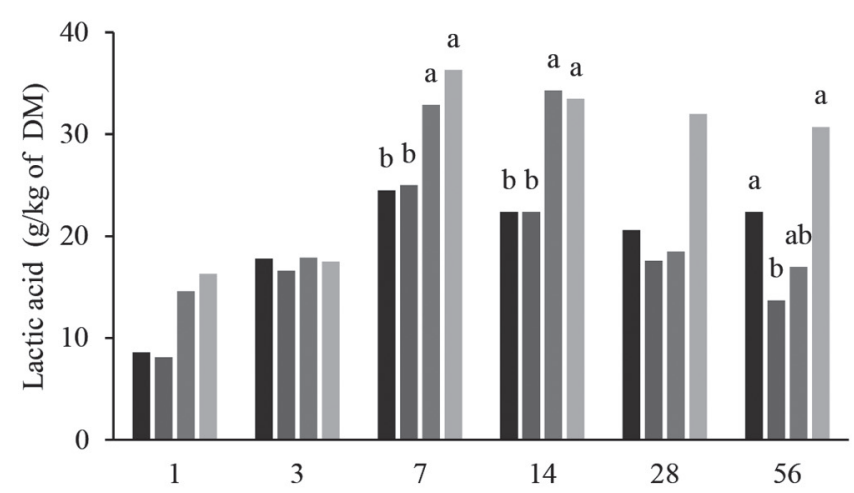

(c)

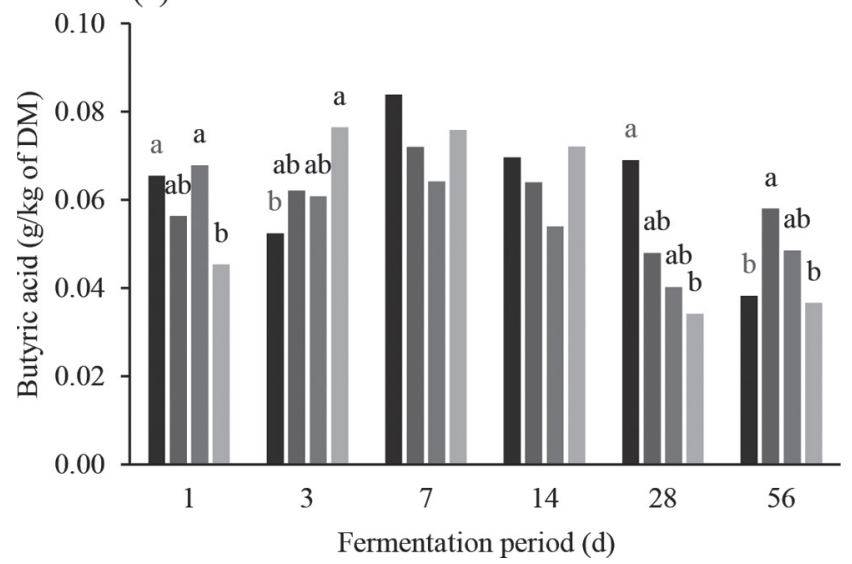

(b)

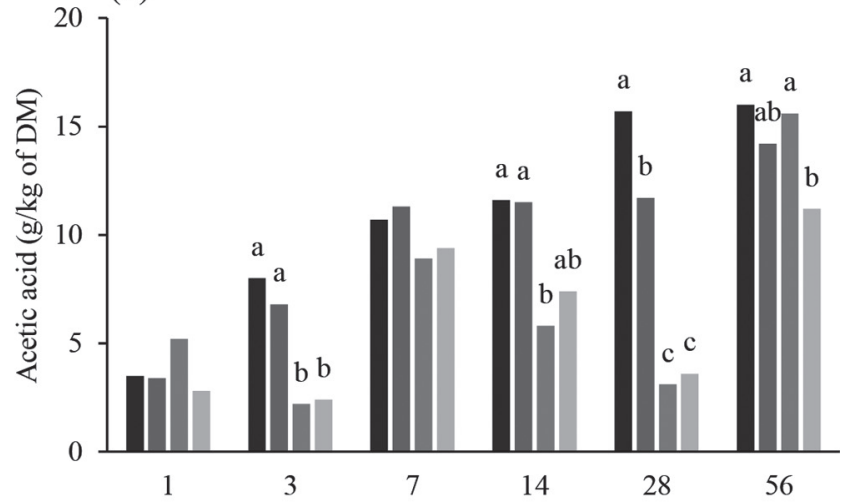

(d)

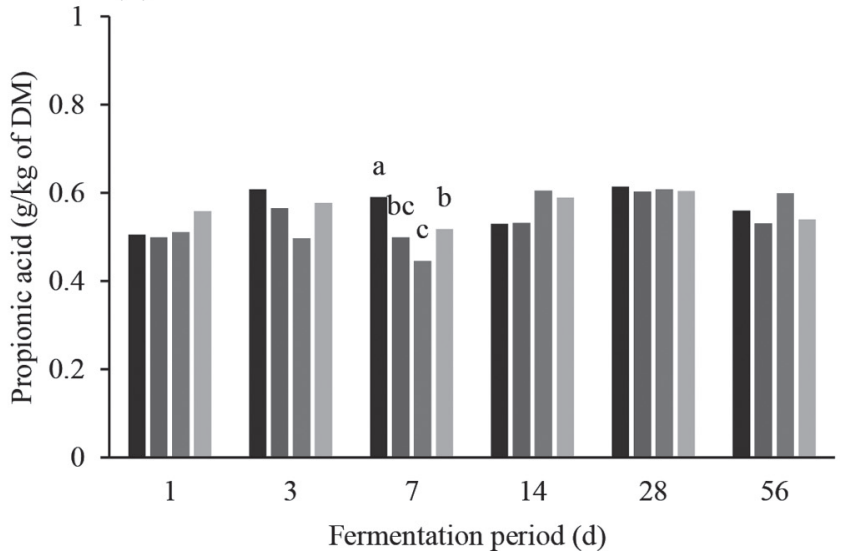

Figure 3. Concentrations of lactic acid (a), acetic acid (b), butyric acid (c), and propionic acid (d) in alfalfa silages as a function of microbial inoculant within each period of fermentation. Means followed by different letters $(\mathrm{a}-\mathrm{c})$ are different according to the predicted difference $(P<$ 0.05). CTRL $=$ control (without inoculant); CIN = commercial inoculant, Sil-All $4 \times 4$ W.S. (Alltech, Sao Paulo, Brazil); S1 $=$ Pediococcus acidilactici, strain 10.6; S2 = Pediococcus pentosaceus, strain 6.16.

tiate the production of ammonia through several deamination reactions and severely compromise $\mathrm{pH}$ reduction (Seale, 1986). Enterobacteria usually grow until 7 d of fermentation when LAB dominate fermentation and replace that microbial group (Luis and Ramirez, 1988). However, enterobacteria may be found in silage until $\mathrm{d}$

Table 3. Means of microbial populations (fresh weight basis) in alfalfa silage, considering 6 periods of fermentation (1, 3, 7, 14, 28, and 56 d), in log colony-forming units per gram

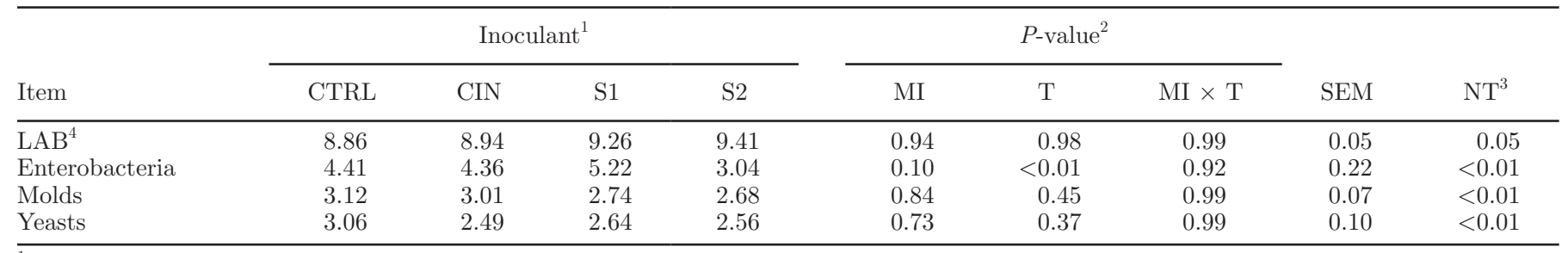

${ }^{1} \mathrm{CTRL}=$ control (without inoculant); CIN = commercial inoculant, Sil-All $4 \times 4$ W.S. (Alltech, Sao Paulo, Brazil); S1 = Pediococcus acidilactici, strain 10.6; $\mathrm{S} 2=$ Pediococcus pentosaceus, strain 6.16 .

${ }^{2} \mathrm{MI}=$ effect of inoculant; $\mathrm{T}=$ effect of period; $\mathrm{MI} \times \mathrm{T}=$ effect of $\mathrm{MI} \times \mathrm{T}$ interaction.

${ }^{3}$ Normality test: hypothesis tested by the Shapiro-Wilk test with $\alpha=0.05$ and H0: normal distribution and H1: not H0.

${ }^{4}$ Lactic acid bacteria. 
Table 4. Chemical composition ( $\mathrm{g} / \mathrm{kg}$ OF DM, unless otherwise stated) of alfalfa silage treated with inoculant at $56 \mathrm{~d}$ of fermentation

\begin{tabular}{|c|c|c|c|c|c|c|}
\hline \multirow[b]{2}{*}{ Item } & \multicolumn{4}{|c|}{ Inoculant $^{1}$} & \multirow[b]{2}{*}{ SEM } & \multirow[b]{2}{*}{$P$-value } \\
\hline & CTRL & CIN & S1 & S2 & & \\
\hline $\mathrm{DM}\left(\mathrm{g} / \mathrm{kg}\right.$ of $\left.\mathrm{FM}^{2}\right)$ & 300 & 304 & 307 & 311 & 0.6 & 0.06 \\
\hline $\mathrm{CP}$ & $170^{\mathrm{b}}$ & $184^{\mathrm{a}}$ & $179^{\mathrm{ab}}$ & $180^{\mathrm{ab}}$ & 0.2 & 0.01 \\
\hline ADIN & 56.5 & 46.2 & 51.8 & 47.9 & 0.2 & 0.17 \\
\hline NDF & 355 & 358 & 346 & 341 & 0.3 & 0.25 \\
\hline $\mathrm{ADF}$ & 250 & 249 & 250 & 235 & 0.3 & 0.27 \\
\hline Lignin & 58.5 & 57.9 & 57.3 & 57.1 & 0.1 & 0.95 \\
\hline Ash & 161 & 162 & 163 & 159 & 0.4 & 0.59 \\
\hline
\end{tabular}

${ }^{\mathrm{a}, \mathrm{b}}$ Means within a row with different superscripts are different according to the predicted difference $(P<0.05)$. ${ }^{1}$ Inoculant: CTRL $=$ control (without inoculant) CIN $=$ commercial inoculant, Sil-All $4 \times 4$ W.S. (Alltech, Sao Paulo, Brazil); $\mathrm{S} 1$ = Pediococcus acidilactici, strain 10.6; S2 = Pediococcus pentosaceus, strain 6.16.

${ }^{2}$ Fresh matter.

30 after ensiling because they are able to grow under anaerobic conditions and protect themselves while under adverse conditions, including under extremely low $\mathrm{pH}$ (Pereira et al., 2007). Although the MI and T did not affect the Y\&M counts, the final populations of these microbial groups in silages decreased compared with those in forage before ensiling. In addition, we did not expect effects of the new strains (S1 and S2) on the number of $\mathrm{Y} \& \mathrm{M}$, because their antimicrobial activity may be related to the production of bacteriocins that do not affect gram-negative microorganisms (Hernández et al., 2005).

No effect was found of MI on the chemical composition of alfalfa silage at $56 \mathrm{~d}(P<0.05$; Table 4$)$. The contents of DM, CP, and NDF were similar to those found by Contreras-Govea et al. (2013), who reported values of $336 \mathrm{~g} / \mathrm{kg}, 190 \mathrm{~g} / \mathrm{kg}$ of $\mathrm{DM}$, and $317 \mathrm{~g} / \mathrm{kg}$

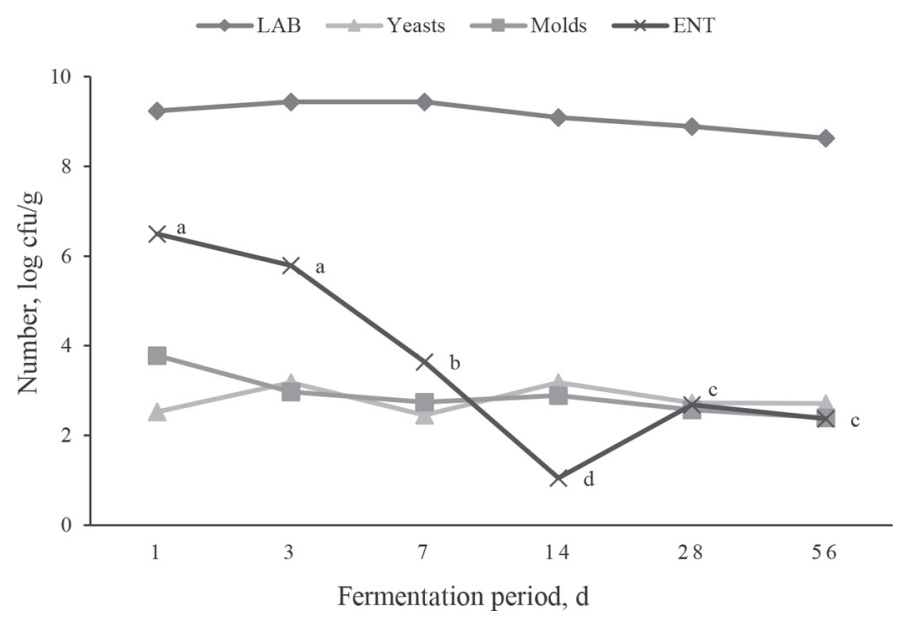

Figure 4. Number of lactic acid bacteria (LAB), mold and yeasts (fresh basis weight), and number of enterobacteria (ENT) in alfalfa silage (fresh basis weight) over the fermentation period. Means followed by different letters $(\mathrm{a}-\mathrm{d})$ are different according to the predicted difference $(P<0.05)$. of DM, respectively, in alfalfa silages treated with $L$. plantarum.

\section{CONCLUSIONS}

The strains $P$. acidilactici 10.6 and $P$. pentosaceus 6.16 obtained from a tropical legume demonstrated potential as silage inoculants for alfalfa grown in the tropics because of their ability to grow fast and dominate the silo environment. Inoculation with these potentially bacteriocinogenic strains resulted in a fermentation that rapidly dropped $\mathrm{pH}$ from the first day of ensiling, was homolactic, with lower concentrations of acetic acid than in silages that were either untreated or treated with a commercial LAB inoculant. The results from this study demonstrate that the fermentation profile of alfalfa silage in tropical conditions was markedly improved with the application of $P$. pentosaceus 6.16 . More research needs to be conducted to define the viable dose and the consistency of the effects observed in the present study.

\section{ACKNOWLEDGMENTS}

This research was supported by the FAPEMIG (Fundação de Amparo à Pesquisa do Estado de Minas Gerais, Belo Horizonte, MG, Brazil) CNPq (Conselho Nacional de Desenvolvimento Científico e Tecnológico, Brasília, Brazil), and CAPES (Coordenação de Aperfeiçoamento de Pessoal de Nível Superior, Brasília, Brazil) foundations

\section{REFERENCES}

Amado, I. R., C. Fucinõs, P. Fajardo, N. P. Guerra, and L. Pastrana. 2012. Evaluation of two bacteriocin-producing probiotic lactic acid bacteria as inoculants for controlling Listeria monocytogenes in grass and maize silages. Anim. Feed Sci. Technol. 175:137-149. 
AOAC (Association of Official Analytical Chemistry). 1990. Official Methods of Analysis. 15th ed. Association of Official Analytical Chemistry, Arlington, VA.

Bolsen, K. K., C. Lin, B. E. Brent, A. M. Feyerherm, J. E. Urban, and W. R. Aimutis. 1992. Effect of silage additives on the microbial succession and fermentation process of alfalfa and corn silages. J. Dairy Sci. 75:3066-3083.

Coblentz, W. K., R. E. Muck, M. A. Borchardt, S. K. Spencer, W. E. Jokela, M. G. Bertram, and K. P. Coffey. 2014. Effects of dairy slurry on silage fermentation characteristics and nutritive value of alfalfa. J. Dairy Sci. 97:7197-7211.

Contreras-Govea, F. E., R. E. Muck, G. A. Broderick, and P. J. Weimer. 2013. Lactobacillus plantarum effects on silage fermentation and in vitro microbial yield. Anim. Feed Sci. Technol. 179:61-68.

Contreras-Govea, F. E., R. E. Muck, D. R. Mertens, and P. J. Weimer. 2011. Microbial inoculant effects on silage and in vitro ruminal fermentation, and microbial biomass estimation for alfalfa, bmr corn, and corn silages. Anim. Feed Sci. Technol. 163:2-10.

Deriaz, R. E. 1961. Routine analysis of carbohydrate and lignin in herbage. J. Sci. Food Agric. 12:150-160.

Detmann, E., and S. C. Valadares Filho. 2010. On the estimation of non-fibrous carbohydrates in feeds and diets. Arq. Bras. Med. Vet. Zootec. 62:980-984.

Dewhurst, R. J., W. J. Fisher, J. K. S. Tweed, and R. J. Wilkins 2003. Comparison of grass and legume silages for milk production. Production responses with different levels of concentrate. J. Dairy Sci. 86:2598-2611.

Ferreira, D. J., R. P. Lana, A. M. Zanine, E. M. Santos, C. M. Veloso, and G. A. Ribeiro. 2013. Silage fermentation and chemical composition of elephant grass inoculated with rumen strains of Streptococcus bovis. Anim. Feed Sci. Technol. 183:22-28.

Filya, I., R. E. Muck, and F. E. Contreras-govea. 2007. Inoculant effects on alfalfa silage: Fermentation products and nutritive value. J. Dairy Sci. 90:5108-5114.

Heinritz, S. N., S. D. Martens, P. Avila, and S. Hoedtke. 2012. The effect of inoculant and sucrose addition on the silage quality of tropical forage legumes with varying ensilability. Anim. Feed Sci. Technol. 174:201-210.

Hernández, D., E. Cardelle, and V. Zárate. 2005. Antimicrobial activity of lactic acid bacteria isolated from Tenerife cheese: Initial characterization of plantaricin TF 711, a bactriocin-like substance produced by Lactobacillus plantarum TF 711. J. Appl. Microbiol. 99:77-84

Kung, L. Jr., C. C. Taylor, M. P. Lynch, and J. M. Neylon. 2003. The effect of treating alfalfa with Lactobacillus buchneri 40788 on silage fermentation, aerobic stability, and nutritive value for lactating dairy cows. J. Dairy Sci. 86:336-343.

Licitra, G., T. M. Hernandez, and P. J. Van Soest. 1996. Standardization of procedures for nitrogen fractionation of ruminant feeds. Anim. Feed Sci. Technol. 57:347-358.

Luis, L., and M. Ramirez. 1988. Evolución de la flora microbiana en ensilaje de king grass. Pastos y Forrajes 11:249-253.

Magalhães, V. J. A., and P. H. M. Rodrigues. 2003. Performance of lactating dairy cows fed alfalfa haylage with microbial inoculant. Rev. Bras. Zootec. 32:2016-2022.

Mahanna, B. 1994. Proper management assures high-quality silage, grains. Feedstuffs $12-15$
Mantovani, H. C., and J. B. Russell. 2003. Inhibition of Listeria monocytogenes by bovicin HC5, a bacteriocin produced by Streptococcus bovis HC5. Int. J. Food Microbiol. 89:77-83.

McDonald, P., and A. R. Henderson. 1962. Buffering capacity of herbage samples as a factor in ensilage. J. Sci. Food Agric. 13:395-400.

Mertens, D. R. 2002. Gravimetric determination of amylase treated neutral detergent fiber in feeds with refluxing in beaker or crucibles: Collaborative study. J. AOAC Int. 85:1217-1240.

Muck, R. 1996. Inoculant of silage and its effects on silage quality. Pages 43-52 in Informational Conference with Dairy and Forage Industries. US Dairy Forage Research, Madison, WI.

Muck, R. E. 1988. Factors influencing silage quality and their implications for management. J. Dairy Sci. 71:2992-3002.

Muck, R. E. 2010. Silage microbiology and its control through additives. Rev. Bras. Zootec. 39:183-191.

Muck, R. E., and L. Kung Jr. 2007. Silage production. Pages 618-633 in Forages, Volume II: The Science of Grassland Agriculture. 6th ed. R. F. Barnes, C. J. Nelson, K. J. Moore, and M. Collins, ed. Blackwell Publishing, Ames, IA.

Oude Elferink, S. J. W. H., J. Krooneman, J. C. Gottschal, S. F Spoelstra, F. Faber, and F. Driehuis. 2001. Anaerobic conversion of lactic acid to acetic acid and 1,2-propanediol by Lactobacillus buchneri. Appl. Environ. Microbiol. 67:125-132.

Pahlow, G., R. E. Muck, and F. Driehuis. 2003. Microbiology of ensiling. Silage science and technology. Proc. Madison: ASCSSA-SSSA Agron. 42:31-93.

Pedroso, A. F., L. G. Nussio, S. F. Paziani, D. R. S. Loures, M. S. Igarasi, R. M. Coelho, I. H. Packer, J. Horii, and L. H. Gomes. 2005. Fermentation and epiphytic microflora dynamics in sugar cane silage. Sci. Agric. 62:427-432.

Pereira, O. G., K. D. Rocha, and C. L. L. F. Ferreira. 2007. Chemical composition, characterization, and population of microorganisms on elephantgrass "Cameroon" (Pennisetum purpureum, Schum) and its silages. Rev. Bras. Zootec. 36:1742-1750.

Rangrab, L. H., P. R. F. Mühlbach, and J. L. Berto. 2000. Alfalfa silage harvest at the early flowering stage and submitted to wilt and action of biological additives. Rev. Bras. Zootec. 29:349-356.

Rodrigues, P. H. M., L. F. S. Almeida, C. S. Lucci, L. Melotti, and F. R. Lima. 2004. Efeitos da adição de inoculantes microbianos sobre o perfil fermentativo da silagem de alfafa adicionada de polpa cítrica. Rev. Bras. Zootec. 33:1646-1653.

Santos, E. M., O. G. Pereira, R. Garcia, C. L. L. F. Ferreira, J. S Oliveira, and T. C. Silva. 2014. Effect of regrowth interval and a microbial inoculant on the fermentation profile and dry matter recovery of guinea grass silages. J. Dairy Sci. 97:4423-4432.

Seale, D. R. 1986. Bacterial inoculants as silage additives. J. Appl. Bact. Symp. Supplement. 61:9S-26S.

Silva, M. P. S., H. C. Mantovani, O. G. Pereira, and W. F. Souza. 2012. Screening of bacteriocinogenic lactic acid bacteria from tropical legume silage. Joint Annual Meeting ASAS ADSA, 2012, Phoenix, AZ. J. Anim. Sci. 90:540.

Van Soest, P. J., and J. B. Robertson. 1985. Analysis of forages and fibrous foods. AS 613 Manual. Dep. Anim. Sci., Cornell Univ., Ithaca, NY.

Whiter, A. G., and L. Kung Jr.. 2001. The effect of a dry or liquid application of Lactobacillus plantarum MTD1 on the fermentation of alfalfa silage. J. Dairy Sci. 84:2195-2202. 